\title{
Collaborative value co-creation in Community Sports Trusts at football clubs
}

\author{
Marcelo P. Castro-Martinez \\ University of Manchester - Manchester Business School \\ Prof. Paul R. Jackson \\ University of Manchester - Manchester Business School
}

Corporate Governance - Special Issue on Governance and CSR Management in Sport

\section{Introduction:}

Sports clubs are subject to the same pressures as other commercial organisations to go beyond purely financial objectives and accept that they have broader social responsibilities (Freeman et al. 2010). Furthermore, other researchers have called for sport to adopt a strategic approach to their social responsibility schemes (Sheth and Babiak, 2010), since social projects that are "poorly linked to core business objectives are therefore less likely to be taken seriously and succeed” (Levermore, 2010 p. 223). However, less attention has been paid to ways in which sport, and football in particular, can achieve positive synergies between commercial and social objectives (Breitbarth and Harris, 2008). Although these authors call for the integration of social projects in a way that furthers the development of the game and creates additional value for stakeholders, the literature is yet to answer the call for the "establishment of a best practice code" (Michie and Oughton, 2005 p. 529) that prescribes ways of identifying and taking advantage of opportunities for the co-creation of value between clubs and their stakeholders. The need for "best practice" is particularly important in English football, because of the discrete experience and expertise among clubs, ranging from some with more than twenty five years of engagement with their local community, to others that started less than five years ago.

Building on Breitbarth and Harris' (2008) call for "football to embrace CSR as an opportunity-driven rather than problem-driven concept” (p. 201), this paper draws upon recent developments in the business literature and introduces a process framework for achieving collaborative co-creation of social and economic value that aims at helping clubs develop a social strategy, the use of club "resources and capabilities to meet both social objectives and financial performance objectives” (Husted et al., 2012 p. 3). The authors make this contribution to help this industry balance the tension between the longterm strategic vision required by the clubs' social projects, and the short-term objectives of having to win every week, balancing the finances of an organization in which key employee wages (players) represent 67\% of revenues (Gibson, 2013), while simultaneously being stewards of a community symbol. This conceptual paper is informed by an on-going multi-case study of four English Premier League clubs and the independent charitable organisations or Community Sports Trusts (from this point on CST) associated with them. These clubs were purposely selected to compare discrete business models, revenues and football objectives so we can further our understanding on how these clubs integrate the CST into their overall business 
strategy. Furthermore, by understanding the drivers for this integration, our research will contribute to answer the question posed in the CSR in sport literature: "[i]s there a need to better integrate CSR across all aspects of the organization rather than consider it the role of a particular department or a specialized function?” (Paramio-Salcines et al., 2013 p. 346). The evidence we present in this paper in order to illustrate and bring our process framework "to life" (Smart, 2009 p. 303), is drawn from interviews with officials at the clubs and key stakeholder groups (supporter groups, national and European governing bodies, grantors, sponsors and the media).

The paper is divided into three sections. The first section provides a brief introduction to the community sports trust model and its limitations. The second section discusses the proposed process framework for achieving collaborative co-creation of social and economic value and unpacks the theoretical underpinnings for this research including specific strategies to expand the integrated creation of economic, football and social value. The last section summarizes the aims of this conceptual paper and implications for future research.

\section{The Community Sports Trust model}

The CST is "a charitable organisation that has a direct association with a football club, yet at the same time has structural, financial and strategic independence” (Walters and Chadwick, 2009 p. 52). The organisation is linked to the club through a licensing agreement, has its own Board of Trustees and Executive team that develop and implement the club's own social schemes, and also execute schemes developed and largely-funded by the Premier League and its social partners (Walters and Panton, 2014). The schemes focus on areas such as community cohesion, education, health, sports participation and international projects (Morgan, 2013).

This model of governance was one of the two recommendations from a research study funded by the Football Foundation Community and Education (C\&E) Panel that ran from October 2002 to October 2005 (Brown et al., 2006). The authors identified several advantages for this model. Independence protects the CST from the financial pressures of the football club. It can also benefit from favourable tax rates and from raising funds from local governments, grant making trusts and the general public. Lastly, by being monitored by the Charity Commission, it can get valuable guidance and "build public confidence" (p. 25).

Although previous research has recognised the exemplary work that clubs do in their communities (Chadwick, 2009), the current model is yet to succeed in addressing the second recommendation from the Football Foundation study: the need for community issues to cut "across the full range of football clubs' activities" (Brown et al., 2006 p. 5) and it therefore "absolv[es] the rest of the club from responsibility for community relations” (p. 22). This is a major problem since management research has found that a strategic approach to social engagement offers a better chance for positive social and economic value creation (Husted et al., 2012). Therefore, although other researchers have highlighted the social engagement features within sport such as youth appeal, positive health impact and social interaction (Smith and Westerbeek, 2007); and its unique resources such as stadia, signage and ticket donations (Babiak and Wolfe, 2009), the current model prevents clubs from fully understanding and leveraging the value that the CST could bring to the club in terms of football value (i.e. talent scouting), and economic 
value (i.e. as a valuable complement to sponsors that lack the qualities to be perceived as involved at the grassroots level (Levermore, 2010)). In regards to the club relationship with external stakeholders, the current model prevents the "outward-facing” (Brown et al., 2006 p. 5) culture of the CST to influence the inward-facing culture of football clubs.

As we will discuss in the following section, the theoretical underpinnings of our process framework address each of these issues. The process framework leads clubs to a better understanding of their environment including its sources of opportunity and obligation and highlights the need for leaders to have the competence and genuine desire to engage with club stakeholders. It also illustrates how these relationships are governed so that the clubs can have their self-interest constrained as they search for incentives for further engagement. Moreover, it explicates how value is always co-created by social actors and how to simultaneously pursue and expand social, football and commercial objectives. Lastly, the process framework integrates these theoretical underpinnings into a decisionmaking process that can be replicated by less-developed clubs and operationalised by other researchers.

\section{Process Framework}

From a behavioral perspective, “corporate governance research addresses the nature of interactions and relationships between the firm and its stakeholders in the process of decision making and control over firm resources” (van Ees et al., 2009 p. 307). Value is defined as the way those resources are combined innovatively to increase productivity (Moran and Ghoshal, 1999). In order to understand how value is created within the stakeholder network, the Service Dominant (S-D) Logic framework (Vargo and Lusch, 2004) argues that value is always co-created by actors "through resource integration and service-for-service exchange” (Lusch and Vargo, 2014 p. 10), and defined by the beneficiary (value-in-use). The distinction between producer and consumer of value disappears. Clubs become both producers and consumers in a constellation of actors (or service systems) that integrate their operant resources (e.g. knowledge and skills) to develop value propositions that "establish connections and relationships among service systems" (Vargo et al., 2008 p. 148) in a way that "align firm, customer and societal interests more closely” (Abela and Murphy, 2007 p. 45). At the club level, this alignment is driven by leaders in charge of the design of the club's social strategy, which we discuss in the next sub-section.

\section{Role of Leaders}

Rost (1993) offers a definition of leadership that is consistent with the collaborative essence of S-D logic: "[l]eadership is an influence relationship among leaders and their collaborators who intend real changes that reflect their mutual purposes” (p. 99). We believe that, consistent with this perspective, distributive leadership theory allows us to see leadership as a group activity that operates within and through relationships rather than individual action (Bolden, 2011).

Also, contrary to the dominant agency perspective that sees corporate governance institutions like boards as hindrance to their managers' self-interest in a context of formal 
contracts and rewards, the behavioral perspective see these institutions "as problemsolving institutions that reduce complexity, create accountability, and facilitate cooperation and coordination between stakeholders” (van Ees et al., 2009 p. 308).

Based on the above, the design and implementation of strategy and the consequent process of problem-solving and value co-creation fall beyond the boundaries of the Board of Trustees and the Executive team and includes all other actors within the club, what in the distributive leadership literature is defined as leader plus (Spillane and Diamond, 2007). Therefore, from this point on we will refer to this group as the Leader Plus Team (LPT).

It follows that the LPT would apply strategic leadership skills, made up of both visionary and managerial traits, or "the ability to influence others to voluntarily make day-to-day decisions that enhance the long-term viability of the organization, while at the same time maintaining its short-term financial stability” (Rowe, 2001 p. 81, 82).

Our ongoing research with English Premier League clubs shows evidence of an evolution in some of the CSTs towards trustees and executives with professional profiles that mirror those of executives in leading organisations in the Third Sector. One of the study participants stated that as their competence improves in "delivering against government targets” they are able to participate in more ambitious projects. This is possible because each member of the LPT operates in their "areas of expertise, and all very clear on what the vision and targets are. We have a business plan [...] and it is designed to deliver to community needs [...] so more and more people are coming to our door because of the sophistication of our programmes”. Also, in our interviews with two national grantors, the competence and track record of the Board and Executive team were highlighted as key variables in the grant approval process.

However, as the CST professionalizes and engages in larger social projects, it also risks increasing its strategic decoupling from the rest of the club furthering the need for a unified governance model of club and CST. Towards that goal, we propose a process framework for achieving collaborative co-creation of social and economic value based on the decision-making process introduced by Goodpaster (1991). The author divided the decision-making process in six steps (following the P.A.S.C.A.L. acronym). The six steps are perception, analysis, synthesis, choice, action, and learning (Goodpaster, 1991 p. 56).

Figure 1 about here

Step 1: Perception of the service ecosystem

Strategic leadership does not occur in a vacuum "but rather in a socially situated context and by individuals whose interpretation of the context is itself socially constructed or constituted” (Westphal and Zajac, 2013 p. 608). In S-D Logic, context is the service ecosystem, a spontaneous structure of social and economic actors operating in time and space to “(1) co-produce service offerings, (2) engage in mutual service provision, and 
(3) co-create value” (Vargo and Lusch, 2011 p. 185). Therefore, the LPT will drive, influence and, to some degree, control the market by focusing on resources and opportunities for value creation as it constantly searches for solutions to existing problems (Lusch and Vargo, 2014), influenced by the environment, the industry and what is important to each stakeholder group (Hult et al., 2011). Perception of the ecosystem is about "fact-gathering about the options available and their short- and long-term implications" (Goodpaster, 1991 p. 56). However, this perception is limited by bounded rationality, the imprecise and selective processing of information that limits awareness and cause inefficiencies in decision-making (van Ees et al., 2009).

According to the literature, the LPT perceives the industry environment through two variables: dynamism, the perceived rate of change and difficulty in predicting external events, and munificence, the availability of resources to support growth from resources developed internally or from market, private and public sources (Husted et al., 2012). Our research shows evidence for both variables. We have seen clubs accommodate their value propositions based both on changes in their social environment (such as a spike in mental health problems in the local community; or cuts in government funding due to the 2008 financial crisis) and on partnership opportunities that complement their operant resources (i.e. implementing a football social inclusion project in close collaboration with a law enforcement programme by the local police). Additionally, the history and narrative of the club (the story they tell about themselves) appear to be a powerful incentive in the design of a social strategy, as we will discuss below. In our research, clubs usually refer to their foundational principles as the raison d'être for their work in the community; and this is not unique to the English Premier League. For example, FC Barcelona with its motto of 'more than a club' stands not only for their representation of the region of Cataluña, but also for their sensibility towards social issues at a local and international levels. This was showcased in 2006 with the agreement they signed with UNICEF, that included a yearly commitment of 1.5 million Euros and the placement of the UNICEF logo on the FCB shirt (Fundació FC Barcelona, 2014). This agreement opened up new opportunities for working with other international organisations such as the Gates Foundation and the InterAmerican Development Bank. Examples just as this illustrate the application of our process framework by showing how football clubs can work as partners with external stakeholders in the co-creation of both economic and social value. In the next step of our process framework, we discuss how clubs identify the available alternatives like the examples shown above, in order to position themselves as socially responsible in a way that fits with their narrative.

\section{Step 2: Analysis: stakeholders analysis and social contracts}

Stakeholder thinking (Freeman, 1984) is essentially about "managing potential conflict stemming from divergent interests" (Frooman, 1999 p. 193). However, the analysis step goes beyond a simple mapping of a stakeholder network and identifying their often conflicting stakes (Fassin, 2009). If an integrated co-creation of social and economic value is to be achieved, clubs and their stakeholders need to focus on "an effort to clarify systematically” (Goodpaster, 1993 p. 7) the available alternatives to the decision-maker, including the "relevant sources of obligation" that the nature of each of these relationships entails. 
To identify these sources of obligation in a way which is consistent with a behavioural approach to corporate governance and S-D logic, Integrative Social Contracts Theory (from this point on ISCT), "defines correct ethical behavior through the device of a hypothetical social contract emphasizing the moral understandings of living members of economic systems and organisations” (Donaldson and Dunfee, 1995 p. 86). These contracts are governed at a macro level by hypernorms, the "fundamental moral precepts for all human beings” (p. 95-96); and at the micro-level by norms of conduct created by the community to address the common sense issues that moral theory cannot fully guide. ISCT is particularly useful to understand and re-evaluate the social contracts between the clubs and their key stakeholders. For example, in the case of fans, the CST plays an important role for fans, as one study participant put it, in "building an extra layer of loyalty...just enforcing and endorsing the vision and mission and that set of values that underpin [the club] and [club] in the Community". However, although the representatives of clubs' supporter groups that we interviewed echoed this sentiment, they believe that their most important issues are not being addressed. We discuss this in detail in the next step of our process framework.

\section{Step 3: Synthesis: stewardship}

The third step in the process framework builds on the analysis of the rights, obligations and communities identified in step two, and involves a synthesis process with the LPT as steward of a cultural asset that is part of the heritage of the community. The synthesis process aims at serving the ecosystem through balancing the tensions between community sustainability and stakeholder consequences, and the commitment to what is best for the club. The stewardship role of the LPT follows what (Goodpaster, 1993 p. 16) calls "the utilitarian 'greatest good' principle, and contractarian fairness principles in policies affecting stakeholders” (Goodpaster, 1993 p. 16).

The stewardship concept is particularly important in the clubs' relationship with their fans, defined by one of our club participants as the "golden thread between both the club and the community programme”. Although fans have adapted, out of necessity, to football's new common sense of market variables (revenues, efficiency and profits) taking over cultural symbols (tradition, social cohesion and ties to local community), they still "share strong bonds, a common identity and a sense of 'moral ownership' of their football club” (Kennedy, 2012 p. 343). This moral ownership, also termed "fan equity, reduces the likelihood of switching allegiances" (Walters and Tacon, 2013 p. 238) but in return, as part of the club-fan social contract, implies fan-perceived entitlements such as reduced ticket pricing, investment in a winning team and redevelopment of stadia surroundings (Millward, 2011). Although all clubs in our sample argued that they have made efforts to cap ticket pricing and made ticket available for underprivileged groups and those that volunteered their time for worthy causes, a third of fans feel that they are no longer able to afford season ticket prices (Preston, 2013).

From a behavioral perspective of corporate governance, these conflicts are addressed through political bargaining between groups with different objectives and priorities (van Ees et al., 2009): on the one hand, the entrepreneurial force of the clubs' owners, which provides direction and is considered legitimate if it leads to performance. The counterweight to this force is social fragmentation, a force made up of the institutions, 
rules and practices that "prevent power from being concentrated" (Gomez and Korine, 2008 p. 7). These two political forces are paradoxically opposed yet validate each other and are mutually reinforced by public opinion, "the manifestation via the media of communication of the collective sentiment of broader society that, in the final analysis, establishes what is and what is not acceptable” (Gomez and Korine, 2008 p. 206).

Evidence from our interviews with supporter groups show that fans from rival clubs have realised that they have more in common than they previously thought and have started to collaborate and mobilise on issues that are of common interest (i.e. standing terraces, affordable away ticket pricing, etc.). Supported by the amplifying power of social media, they had some success in achieving their objectives by mobilising against the Premier League and its sponsors. Moreover, their campaign for safe standing has caught the attention of one of England major political parties that has included it as part of their 2015 General Election pledge (Conway, 2014).

The synthesis step situates the LPT in relation to its environment but also acts as a constraint on self-interest (Freeman et al.2010). Paradoxically, this constraint opens new opportunities for creating both social and economic value, as we will discuss in the next step of our process framework.

\section{Step 4: Choice - Social Strategy}

Put simply, this step relates to selecting "among the available options based on the synthesis” (Goodpaster, 1991 p. 56). The previous steps lead clubs to develop their social strategy, "a portfolio of social action projects” (Husted et al., 2012 p. 2) that must fulfill the dual demands of creating social and economic value. Our ongoing study shows that clubs can create both social and economic value if their strategies are designed properly. For example, in the case of a key stakeholder group like sponsors, moving beyond 'logo placement' to social projects with longer-term horizons, serves to strengthen the commercial relationship between the two parties. Everton FC has built a ten-year relationship with its main sponsor following this kind of strategy. In renewing this agreement, the President and CEO for the sponsor (Thai Beverage) stated that their "sponsorship with Everton football team is our proudest accomplishment, as we are inspiring people, especially youngsters, regardless of status to become responsible people in society, with positive thinking and attitude - all gained through football”

(Sirivadhanabhakdi, 2014). Therefore, during this step the LPT should develop its social strategy by engaging in the two processes of strategic social planning and strategic social positioning (Husted et al., 2012), in a way which is informed by the narrative of the club and influenced by the club's competitive environment.

The first process is strategic social planning, and this requires setting long-term goals, the specific actions to achieve those goals and the allocation of resources to carry them out. In the dynamic and unstable environment of most Premier League clubs, planning for the long term is problematic since the main focus is on the short-term objective of winning every week. Clubs are said to engage in strategic social planning depending on: (a) how they define a program and agenda for social action, (b) the intensity of investment in social programs, (c) the commitment of employees, and (d) how they measure the outcomes of programs (Husted and Allen, 2007). Therefore, strategic social planning 
would only be possible for clubs characterized by strong values and highly salient stakeholders, such as civil-society organizations, employees, and governments, among others. Clubs that see the CST as a genuine extension of what the club is really about, rather than what they want stakeholders to perceive, would engage in social planning, especially since "fans may be much more responsive to team performance than to teams' involvement in CSR activities” (Waddington et al., 2013 p. 40). As one of our study participants put it, "I think that the reason why our programme is very different is because we have a very sincere and genuine reason to connect with our community. Something we have done before people discussed CSR contributions”.

The second process is strategic social positioning, and this refers to the extent to which the club is proactive in responding to social issues relative to its competitors. It can do this in a number of ways: by responding to changed expectations in its corporate practices, by going beyond the minimum required by regulators, and by committing more than its competitors to social projects (Husted et al., 2012 p. 7). Along this lines, one of our participants expressed that “we do tackle issues that maybe other people wouldn't want to engage with. I mean mental health, dementia, [...] working with recovering drug addicts and alcoholics. Maybe some clubs would be resistant to align themselves with some very high profile and sensitive social matters, but for [the club] we are very clear that the people within our community who [...] are living with those difficulties should, if we can, be able to receive support from their football club.

Based on the above, a social strategy can generate both social and economic value as long as it is driven by a genuine desire to go beyond just business objectives. The collaborative culture of the CST is key in the implementation of this strategy, as we discuss on the next step of our process framework.

\section{Step 5: Action - implementation through collaboration}

During implementation, actors need to collaborate by negotiating and adapting their value propositions based on learning from their interactions as they search for the best and right combination of resources (Lusch and Vargo, 2014) to achieve both social and economic value. From a behavioral perspective on corporate governance the purpose of the LPT is to enable cooperation not only in terms of conflict resolution and control, but most importantly "by solving problems of cooperation and coordination and engaging in collective processes of organized information and knowledge gathering” (van Ees et al., 2009 p. 308).

We believe it is this stage of collaborative integration of club and CST resources that enables clubs to create collective agency or "the capacity to influence a host of relevant outcomes beyond what individual organizations could do on their own" (Koschmann et al., 2012 p. 333). One way in which they can do this is by co-orienting and organizing communications to attract capital (efforts to acquire economic, social, cultural, and symbolic). For example, the Premier League follows the strategy of matching pound for pound the funding from national partners, while simultaneously allowing clubs to bid for discretionary funding for projects that also have a matching local funder. It is in the implementation step of our framework that clubs can marshal consent by persuading other internal and external stakeholders "to accept a given definition of the situation, an 
agenda for problem solving, a conception of insiders and outsiders, procedural rules, or preferred decisional alternatives” (p. 337).

Successful collaboration to create both social and economic value comes from a virtuous circle of joint action, an iterative process of setting aims that are clearly defined from the outset but can be adjusted as joint tasks are performed. Social schemes can thus be an effective expression of the principle underpinning our framework, building both social and economic value. An example is the Premier League's Kicks Project which is reported to generate about $£ 7$ of social value for each $£ 1$ invested (Nevill and Van Poortvliet, 2011), in addition to the economic value that it generates for the League and its clubs in terms of reputation and goodwill. Service-for-service exchange provides opportunities for additional value being co-created from new resource integrations (Vargo and Lusch, 2011). Other forms of resource integration can generate social and economic value through imaginative service exchanges between stakeholders. In London, for example, clubs are coming together in London United, an initiative started by the London Evening Standard which allows clubs to join forces to access citywide funding that each of them can then use to fund their community coaching activities (Cohen, 2014).

Effective collaboration is challenged by satisficing behavior, the tendency of actors to accept choices or judgments that are "good enough" based on what their pressing needs rather than searching for a more difficult but ultimately optimal solution (van Ees et al., 2009). Furthermore, although social actors in collaborative stakeholder networks can exchange different resources, their objectives are often different as well, even when they agree on the broad advantages of the collaboration (Huxham and Beech, 2003). This tension may nevertheless be empowering when it is recognised by the actors involved and is used to co-create value which is truly shared by each actor, "allow[ing] concepts of CSR, sustainability and the stakeholder approach to find their natural homes, whether at a strategic or a managerial level” (Wheeler et al., 2003).

Learning from iterations of collaborative co-creation of social and economic value and how this process leads to opportunities to expand the value co-creation potential what we will address in final step of our process framework.

Step 6: Learning through co-innovation and imitation

The learning step refers to the "reinforcement or modification (for future decisions) of the way in which the above steps have been taken” (Goodpaster, 1991 p. 56).

From a behavioral perspective, decision making is an "experiential learning process" where "decision makers learn by trial and error what can be done, and they adapt their goals, attention rules, and search rules accordingly”. (van Ees et al., 2009 p. 312).

As the iterations of co-creation through collaboration develop, the ecosystem changes and so does the viability of each actor's system as they develop new "specialized and applied knowledge and skills, service exchanges, and resource integration" (Lusch and Vargo, 2014 p. 71). Learning from these iterations leads to co-innovation by "taking advantage of network effects to apply resources in new ways to create new value for all stakeholders” (Lee et al., 2012 p. 824). Our on-going research with English Premier League clubs shows them competing fiercely at their city's derby but at the same time co- 
creating value by sharing their skills and knowledge to fulfil their social projects within their communities while respecting their gentlemen's agreement not to overstep each other's neighbourhood boundaries.

These iterations of collaboration, learning and co-innovation are fertile ground for clubs to overcome the limitations of the existing Community Social Trust model which is the dominant means that English Premier League clubs use to further their social agendas and expand their social and economic value potential. Our approach builds on the Creating Share Value (CSV) framework (Porter and Kramer, 2006, 2011). We support the authors' argument that the relationship between business and society need not be a zero sum game. A study participant from UEFA, European football's governing body, agrees as well when he stated that "CSR is not at the expense of profits but it's about how profits are being made. And so, if this is part of the football club's philosophy, I think that there is also a way of identifying the added value in terms of financial revenues. If your club is being perceived as socially responsible, that makes it more attractive to your potential sponsors". For Porter and Kramer (2011), "the total pool of economic and social value” (p. 5) can be expanded by the implementation of three strategies that aim at reconciling the clubs' economic and societal objectives: by reconceiving products and markets, by redefining productivity in the value chain and by building supportive industry clusters at the company's locations. We now consider each in turn, giving examples based on interviews in our on-going research. We have found evidence for the first strand of the CSV framework: reconceiving products and markets. Our research with Premier League clubs suggests that as some clubs develop their global footprint, the value propositions from the CSTs are being reconceived and achieve greater strategic importance. Examples from our research include a club expanding its footprint in Asia by attracting corporate partners that must comply with new CSR legislation; another club supporting their main sponsor in CSR activities during a tsunami in the sponsor's country of origin; the City in the Community programme taking a commanding role in the global expansion of Manchester City F.C. as they develop or acquire clubs in the U.S. and Australia respectively (Masanauskas, 2014). The international arena appears to present both new challenges and opportunities for Premier League clubs and for their community work. In particular, it offers a "clean piece of paper", as one study participant put it, to develop the grassroots game overseas while creating social value without the cloud of scepticism that sometimes overshadows their community efforts in England. We have so far found no evidence for the second strand of the CSV framework, reconceiving the clubs' value chain. Beyond a periodic search for cost-efficiencies and a club procurement policy that favours vendors that share the club's "ethos", this is a strategy that could be implemented in the future, as is the case in Germany. In our interview with a German Bundesliga club, the participant discussed partnering with local industry to reduce the club's carbon footprint while using the club as medium to educate its fans about sustainability. Additionally, the UEFA representative we interviewed offered that “compensating [for UEFA's carbon footprint] is a great issue and trying to push our fans to use and travel more on public transport is the right strategy". Lastly, there is some evidence for the third strand of the CSV framework, building supportive industry clusters at the company's locations. Despite clubs being quick to point out that their community work is not a vehicle for talent scouting, one of the clubs in our sample pointed out that their CST will be the face for football festivals and 
assessment centers aiming at bridging the gap between the CST and their Academy. These activities are also being conducted overseas in partnership with club sponsors. Additionally, the Premier League's Chief Executive has argued that schemes like the Kicks Projects should be leveraged to improve England's talent pool and offered the examples of Raheem Sterling and Wilfried Zaha as two players that made it all the way to the national team after being 'discovered' while participating in this scheme (Winter, 2014). Similar examples can also be found in other professional sports like Major League Baseball (USA), where clubs invest in youth academies in the Dominican Republic, an important source of players, while also providing educational facilities and services to the local communities (Babiak, 2010).

Additionally, an indirect opportunity for value creation is that thanks to the prestige and worldwide reach of the Premier League, other clubs and governing bodies overseas may replicate their social strategy through imitation. Therefore, if a club is unclear about how to develop and implement a social strategy, it will copy its competitors' actions further expanding the value creation potential.

\section{Conclusion}

This conceptual paper discussed the shortcomings of the current governance model of Community Sport Trusts in Premier League clubs as a mechanism for meeting their social obligations as well as their football and business objectives. We offer an alternative model based on collaborative value co-creation, together with a process framework through which competent leaders could engage with their local communities to implement social strategies that simultaneously achieve social, football and economic value. The evidence that we have presented shows that some clubs are already applying some of these strategies, and will probably deepen and extend their commitment to their communities since it appears to be not only consistent with the strategy of the club but with the history and narrative that underpin their existence.

The framework can also be instrumental in guiding leaders in less-developed CSTs on how to develop and implement their social strategies, in the understanding that "a good theory has to help managers create value for stakeholders and enable them to live better lives in the real world” (Parmar et al., 2010 p. 411).

The paper also offers the strategies within the Creating Shared Value framework as a roadmap for expanding value co-creation in a way that benefits the clubs and society at large.

As implications for future research, the steps in the conceptual framework can be tested empirically. Another opportunity is to explore how competition from other clubs in the same city influence the focal club's social strategies, or how Government, the media and other important stakeholders pressure the Premier League into strategic social planning. Future studies might also focus on how the international footprint of the CST influences their strategic integration with the rest of the club. Lastly, the LPT might be used as a new unit of analysis in future research.

References: 
Abela, A. V. and Murphy, P. E. (2007) "Marketing with Integrity: Ethics and the ServiceDominant Logic for Marketing", Journal of the Academy of Marketing Science, Vol. 36 No. 1, pp. 39-53.

Babiak, K. (2010) "The Role and Relevance of Corporate Social Responsibility in Sport: A View from the Top", Journal of Management \& Organization, Vol. 16 No. 4, pp. 528-549.

Babiak, K. and Wolfe, R. (2009) "Determinants of Corporate Social Responsibility in Professional Sport: Internal and External Factors", Journal of Sport Management, Vol. 23 No. 6, pp. 717-742.

Barcelona, F. C. (2014) 'Alliance with Unicef', Fundació FC Barcelona [online], available: http://foundation.fcbarcelona.com/projects/detail/card/partnershipwith-unicef [accessed Sep. 15th 2014].

Bolden, R. (2011) "Distributed Leadership in Organizations: A Review of Theory and Research", International Journal of Management Reviews, Vol. 13 No., pp. 251-269.

Breitbarth, T. and Harris, P. (2008) "The Role of Corporate Social Responsibility in the Football Business: Towards the Development of a Conceptual Model", European Sport Management Quarterly, Vol. 8 No. 2, pp.

Brown, A., Crabbe, T. and Mellor, G. (2006) "Football and Its Communities: Final Report", Football Foundation and Manchester Metropolitan University.

Chadwick, S. (2009) "From Outside Lane to inside Track: Sport Management Research in the Twenty-First Century", Management Decision, Vol. 47 No. 1, pp. 191-203.

Cohen, D. (2014) 'London United: Our New Campaign to Change Youngsters' Lives through Football', [online], available: http://www.standard.co.uk/news/londonunited/london-united-our-newcampaign-to-change-youngsters-lives-through-football-9733151.html [accessed Sep. 27th 2014].

Conway, R. (2014) 'Safe Standing: Lib Dems Make 2015 General Election Pledge', BBC [online], available: http://www.bbc.com/sport/0/football/28886330 [accessed Oct 31st 2014].

Donaldson, T. and Dunfee, T. W. (1995) "Integrative Social Contracts Theory", Economics and Philosophy, Vol. 11 No. 1, pp. 85-112.

Fassin, Y. (2009) "The Stakeholder Model Refined", Journal of Business Ethics, Vol. 84 No. 1, pp. 113-135. 
Freeman, R. E. (1984) Strategic Management - a Stakeholder Approach, Cambridge, UK: Cambridge University Press.

Freeman, R. E., Harrison, J. S., Wicks, A. C., Parmar, B. L. and De Colle, S. (2010) Stakeholder Theory: The State of the Art, Cambridge, UK: Cambridge University Press.

Frooman, J. (1999) "Stakeholder Influence Strategies", Academy of Management Review, Vol. 24 No. 2, pp. 191-205.

Gibson, O. (2013) 'Premier League Warned over 'Rich and Poor' Split in Wake of Television Deal', [online], available:

http://www.guardian.co.uk/football/2013/mar/19/premier-league-championshiptv-deal [accessed Apr 30th, 2013].

Gomez, P.-Y. and Korine, H. (2008) Entrepreneurs and Democracy, Business, Value Creation, and Society, Cambridge, UK: Cambridge University Press.

Goodpaster, K. E. (1991) "Business Ethics and Stakeholder Analysis", Business Ethics Quarterly Vol. No. 1, pp. 53-73.

Goodpaster, K. E. (1993) "Moral Consideration and the Environment: Perception, Analysis, and Synthesis", Topoi - Kluwer Academic Publishers, Vol. 12, pp. 5-20.

Hult, G. T., Mena, J. A., Ferrell, O. C. and Ferrell, L. (2011) "Stakeholder Marketing: A Definition and Conceptual Framework", Academy of Marketing Science, Vol. 1, pp. 4465.

Husted, B. W. and Allen, D. B. (2007) "Corporate Social Strategy in Multinational Enterprises: Antecedents and Value Creation", Journal of Business Ethics, Vol. No. 74, pp. 345-361.

Husted, B. W., Allen, D. B. and Kock, N. (2012) "Value Creation through Social Strategy", Business \& Society, Vol. 20 No. 10, pp. 1-40.

Huxham, C. and Beech, N. (2003) "Contrary Prescriptions: Recognizing Good Practice Tensions in Management", Organization Studies, Vol. 24 No. 1, pp. 69-93.

Kennedy, D. (2012) "Football Stadium Relocation and the Commodification of Football: The Case of Everton Supporters and Their Adoption of the Language of Commerce", Soccer \& Society, Vol. 13 No. 3, pp. 341-358.

Koschmann, M. A., Kuhn, T. R. and Pfarrer, M. D. (2012) "A Communicative Framework of Value in Cross-Sector Partnerships", Academy of Management Review, Vol. 37 No. 3, pp. 332-354. 
Lee, S. M., Olson, D. L. and Trimi, S. (2012) "Co-Innovation: Convergenomics, Collaboration, and Co-Creation for Organizational Values", Management Decision, Vol. 50 No. 5, pp. 817-831.

Levermore, R. (2010) "CSR for Development through Sport: Examining Its Potential and Limitations", Third World Quarterly, Vol. 31 No. 2, pp. 223-241.

Lusch, R. F. and Vargo, S. L. (2014) Service-Dominant Logic, Cambridge, UK:

Cambridge University Press.

Masanauskas, J. (2014) 'Melbourne City Football Club Partners with City Council to Promote Cultural Events', [online], available:

http://www.adelaidenow.com.au/sport/football/melbourne-city-football-clubpartners-with-city-council-to-promote-cultural-events/story-fnk6pqha1226959177516 [accessed Sep. 1st 2014].

Michie, J. and Oughton, C. (2005) "The Corporate Governance of Professional Football Clubs in England", Corporate Governance, Vol. 13 No. 4, pp. 517-531.

Millward, P. (2011) The Global Football League: Transnational Networks, Social Movements and Sport in the New Media Age, Basingstoke, UK: Palgrave.

Moran, P. and Ghoshal, S. (1999) "Markets, Firms, and the Process of Economic Development", The Academy of Management Review, Vol. 24 No. 3, pp. 390-412.

Morgan, S. (2013) "The Premier League: A Commitment to Social Resposibility" in Paramio-Salcines, J. L., Babiak, K. and Walters, G., eds., Routledge Handbook of Sport and Corporate Social Responsibility, Oxon, UK: Routledge.

Nevill, C. and Van Poortvliet, M. (2011) "Teenage Kicks - the Value of Sport in Tackling Youth Crime", London, UK: New Philanthropy Capital for Laureus Sport for Good Foundation.

Paramio-Salcines, J. L., Babiak, K. and Walters, G. (2013) "Conclusion: Trends, Challenges and the Future for CSR in Sport" in Paramio-Salcines, J. L., Babiak, K. and Walters, G., eds., Routledge Handbook of Sport and Corporate Social Responsibility, Oxon, UK: Routledge.

Parmar, B. L., Freeman, R. E., Harrison, J. S., Wicks, A. C., Purnell, L. and de Colle, S. (2010) "Stakeholder Theory: The State of the Art", The Academy of Management Annals, Vol. 4 No. 1, pp. 403-445.

Porter, M. and Kramer, M. (2011) "Creating Shared Value", Harvard Business Review, Vol. 89 No. 1-2, pp. 62-77. 
Porter, M. E. and Kramer, M. R. (2006) "Strategy and Society", Harvard Business Review, Vol. 84 No. 12, pp. 78-92.

Porter, M. E. and Kramer, M. R. (2011) "Creating Shared Value", Harvard Business Review, Vol. 89 No. 1-2, pp. 62-77.

Preston, J. (2013) 'One in Three Premier League Fans May Abandon Season Tickets', [online], available: http://www.virgin.com/money/news/one-in-three-premierleague-fans-may-abandon-season-tickets [accessed May 30th 2013].

Rost, J. C. (1993) "Leadership Development in the New Millennium", Journal of Leadership \& Organizational Studies, Vol. 1 No. 1, pp. 91-110.

Rowe, W. G. (2001) "Creating Wealth in Organizations: The Role of Strategic Leadership", The Academy of Management Executive, Vol. 15 No. 1, pp. 81-94.

Sheth, H. and Babiak, K. M. (2010) "Beyond the Game: Perceptions and Practices of Corporate Social Responsibility in the Professional Sport Industry", Journal of Business Ethics, Vol. 91 No., pp. 433-450.

Sirivadhanabhakdi, T. (2014) 'Blues Strike Record Chang Deal', [online], available: http://www.evertonfc.com/news/2014/03/20/blues-strike-record-chang-deal [accessed Sep 13th 2014].

Smart, C. (2009) "Shifting Horizons: Reflections on Qualitative Methods", Feminist Theory, Vol. 10 No. 3, pp. 295-308.

Smith, A. C. T. and Westerbeek, H. M. (2007) "Sport as a Vehicle for Deploying Corporate Social Responsibility", The Journal of Corporate Citizenship; Spring 2007; 25; ABI/INFORM Global, Vol. Spring 2007 No. 25, pp. 43-54.

Spillane, J. P. and Diamond, J. B. (2007) Distributed Leadership in Practice, New York: Teachers College Press.

van Ees, H., Gabrielsson, J. and Huse, M. (2009) "Toward a Behavioral Theory of Boards and Corporate Governance", Corporate Governance: An International Review, Vol. 17 No. 3, pp. 307-319.

Vargo, S. L. and Lusch, R. F. (2004) "Evolving to a New Dominant Logic for Marketing", Journal of Marketing, Vol. 68 No. 1, pp. 1-17.

Vargo, S. L. and Lusch, R. F. (2011) "It's All B2b... and Beyond: Toward a Systems Perspective of the Market", Industrial Marketing Management, Vol. 40, pp. 181-187. 
Vargo, S. L., Maglio, P. P. and Archpru Akaka, M. (2008) "On Value and Value CoCreation: A Service Systems and Service Logic Perspective", European Management Journal, Vol. 26 No., pp. 145-152.

Waddington, I., Chelladurai, P. and Skirstad, B. (2013) "CSR in Sport: Who Benefits?" in Paramio-Salcines, J. L., Babiak, K. and Walters, G., eds., Routledge Handbook of Sport and Corporate Social Responsibility, Oxon, UK: Routledge.

Walters, G. and Chadwick, S. (2009) "Corporate Citizenship in Football: Delivering Strategic Benefits through Stakeholder Engagement", Management Decision, Vol. 47 No. 1, pp. 51-66.

Walters, G. and Panton, M. (2014) "Corporate Social Responsibility and Social Partnerships in Professional Football", Soccer \& Society, Vol. 15 No. 6, pp. 828-846.

Walters, G. and Tacon, R. (2013) "Stakeholder Engagement in European Football" in Paramio-Salcines, J. L., Babiak, K. and Walters, G., eds., Routledge Handbook of Sport and Corporate Social Responsibility, Oxon, UK: Routledge.

Westphal, J. D. and Zajac, E. J. (2013) "A Behavioral Theory of Corporate Governance: Explicating the Mechanisms of Socially Situated and Socially Constituted Agency", The Academy of Management Annals, Vol. 7 No. 1, pp. 607-661.

Wheeler, D., Colbert, B. and Freeman, R. E. (2003) "Focusing on Value: Reconciling Corporate Social Responsibility, Sustainability and a Stakeholder Approach in a Network World", Journal of General Management, Vol. 28 No. 3, pp. 1-28.

Winter, H. (2014) 'Premier League Chief Richard Scudamore’s Crusade to Lift England Football', [online], available:

http://www.telegraph.co.uk/sport/football/competitions/premierleague/10637493/Premier-League-chief-Richard-Scudamores-crusade-to-liftEngland-football.html [accessed Oct. 24th]. 
Fig 1. Process framework for collaborative value co-creation

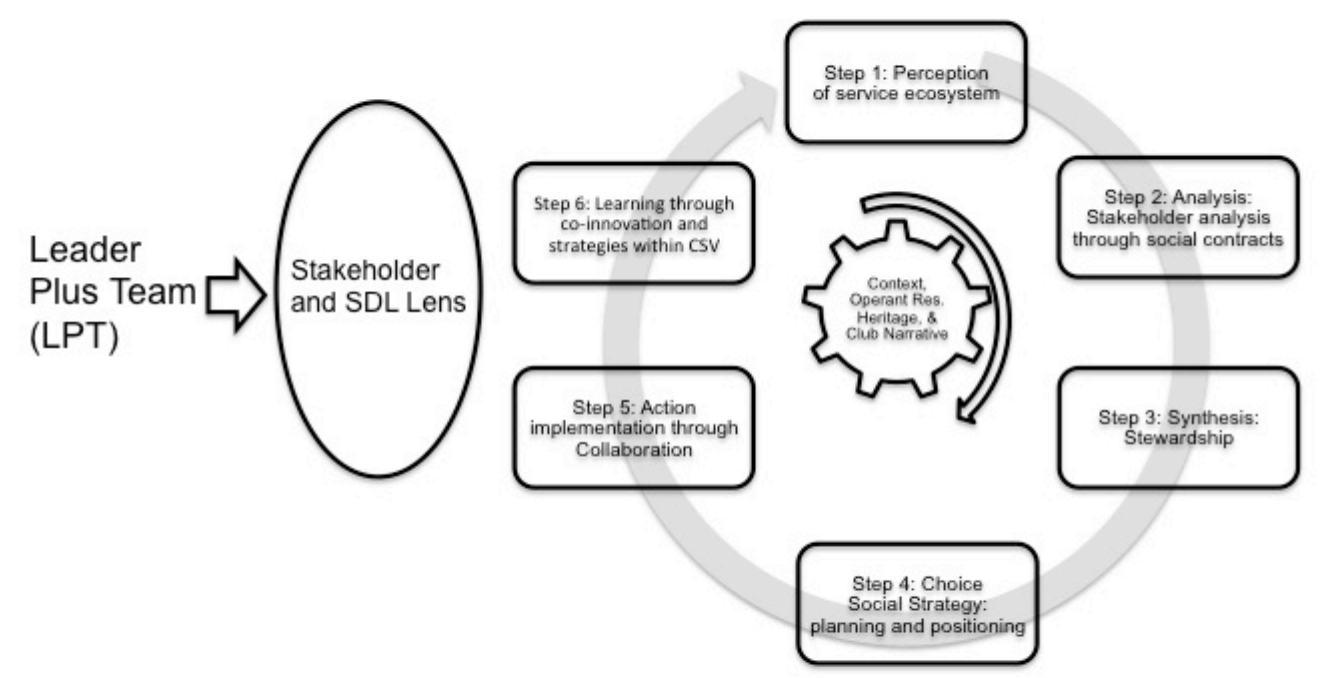

